\title{
ALIENAÇÃO ANTECIPADA E DESTINAÇÃO PRÉVIA DE BENS CONSTRITOS: LIMITES ÉTICOS E JURÍDICOS NO ÂMBITO DA CRIMINALIDADE ECONÔMICA
}

\section{ADVANCE SALE OF ASSETS AND PRIOR DESTINATION OF CONSTRICTED GOODS: ETHICAL AND LEGAL LIMITS ON THE ECONOMIC CRIME SCOPE}

\begin{abstract}
RODRIGO SÁNCHEZ RIOS
Doutorado em Direito Penal e Criminologia pela Università Degli Studi Di Roma Tre, "La Sapienza" . Professor da Pós Graduação stricto sensu da Pontifícia Universidade Católica do Paraná. Professor de Graduação em Direito Penal pela

Pontifícia Universidade Católica do Paraná. Advogado Criminalista rodrigo@sanchezrios.com.br

GUILHERME SIQUEIRA VIEIRA Mestrando em Direito Econômico e Desenvolvimento pela Pontifícia Universidade Católica do Paraná. Graduado em Direito pela mesma instituição. Advogado Criminalista guilhermesv@sanchezrios.com.br
\end{abstract}

\section{RESUMO}

Este artigo versa sobre o instituto da alienação antecipada e destinação prévia de bens apreendidos em razão do cometimento de crimes, seja em procedimentos investigatórios, ou no curso processual. Fez-se uma tomada geral sobre o contexto das medidas assecuratórias no ordenamento brasileiro, versando sobre seus dispositivos e objetivos. Após, demonstrou-se 0 enquadramento da alienação antecipada de bens constritos dentro do direito penal e processual penal, passando a analisa-lo em face das legislações vigentes, dentre elas o decreto-lei $3.689 / 41$ e leis $9.613 / 98$ e $11.343 / 06$. Assim, apontouse o seu alcance e os limites legais atinentes e sua aplicação, não só por critérios teóricos, mas por critérios práticos, utilizando-se de doutrinas nacionais e estrangeiras, além de jurisprudência brasileira.

Palavras-chave: alienação antecipada; globalização; lavagem de dinheiro; medidas assecuratórias; crimes econômicos.

\begin{abstract}
This article deals with the advance sale of assets and the prior destination of constricted assets which were seized because of the commission of crimes, be it at investigative procedures, or at the course of criminal prosecution. The context of real precautionary measures was observed in the Brazilian legal system, dealing with its devices and objectives. After, it was shown where de advance sale of assets would be found into criminal law and criminal procedure law, analyzing it in face of current legislation, among them the decree 3.689/41, law 9.613/98 and law 11.343/06. Therefore, it was pointed its reach e its legal limits relating to its applicability, not only by theoretical criteria, but also with practical criteria, using national and foreign doctrines, as well as Brazilian jurisprudence.
\end{abstract}

Keywords: advance sale of assets; globalization; money laudering; real precautionary measures; economic crimes 


\section{SUMÁRIO}

INTRODUÇAO; 1 NATUREZA JURÍDICA DO INSTITUTO DA ALIENAÇÃO ANTECIPADA E REGULAMENTAÇÃO NORMATIVA; 2 PROCEDIMENTO, EFETIVIDADE E DESTINAÇÃO PRÉVIA; CONCLUSÃO; REFERÊNCIAS.

\section{INTRODUÇÃO}

Em matéria de providências judiciais destinadas a assegurar a eficiência e o resultado do processo criminal, a atenção da doutrina pátria esteve tradicional e primordialmente direcionada às medidas cautelares pessoais ${ }^{1}$. Tal constatação decorre de um ranço histórico de intervenção nas liberdades individuais mediante a aplicação das penas corporais, e também devido às características da sociedade em meio à qual foi redigido o Código de Processo Penal vigente - 1941 - onde a população brasileira era menor e os crimes menos complexos, nos quais os instrumentos empregados e os seus proventos, no mais das vezes, constituíam-se em facas, revolveres e espingardas ${ }^{2}$. Como consequência, a lei penal adjetiva previa dentre o rol das medidas cautelares reais, apenas o sequestro de bens imóveis (artigos 125 a 131 do CPP), sequestro de bens móveis (art. 132 do CPP), especialização e registro da hipoteca legal (artigos 134 e 135 do (PP), arresto de bens imóveis prévio à especialização e registro da hipoteca legal (art. 136 do CPP), e o arresto subsidiário de bens móveis (art. 137 do CPP) ${ }^{3}$.

O cenário contemporâneo, configurado como sociedade de riscos, globalizada e tecnológica ${ }^{4}$, permite o surgimento de condutas delitivas mais sofisticadas, regidas em estruturas organizadas e desenvolvidas em caráter de habitualidade, as quais têm como escopo a

\footnotetext{
${ }^{1}$ MARQUES, José Frederico. Tratado de Direito Processual Penal. São Paulo: Saraiva. 1980.

2 FREITAS, Vladimir Passos de. 0 desafio dos bens apreendidos nas ações penais. Revista Consultor Jurídico. Disponível em: <http://www.conjur.com.br/2011-out-23/segunda-leitura-desafio-bensapreendidos-acoes-penais>. Acesso em 06 maio 2015.

${ }^{3} \mathrm{Na}$ temática do estudo das medidas cautelares reais, na doutrina processual brasileira, o estudo de João Gualberto Garcez Ramos, na obra intitulada A tutela de urgência no Processo Penal brasileiro, representou uma inovação pela importância e sistematização com que estes institutos começaram a ser observados na realidade nacional a partir dos trabalhos deste autor.

${ }^{4}$ Cfr. FIGUEIREDO DIAS, J. de. O direito penal entre a 'sociedade industrial' e a 'sociedade do risco'. Revista Brasileira de Ciencias Criminais, São Paulo. n.33, 2001.p. 39 e ss. Ver também: SCHÜNEMANN, Bernd. Consideraciones Críticas sobre la situación espiritual de la ciência jurídico penal alemana. In: cuadernos de Doctrina y Jurisprudencia Penal, Buenos Aires, n. 2, p. 17-49, abr. 1996. Disponível em: http://derechopublicomd.blogspot.com.br/2012/05/consideraciones-criticas-sobre-la.html. Acesso em: 07 maio 2015. Nessa mesma linha, vide SILVA SANCHEZ, Jesús-María. A expansão do direito penal: aspectos da política criminal nas sociedades pós-industriais (Trad. Luiz Otavio de Oliveira Rocha). In: Séries As ciências criminais no século XXI, v. 11). São Paulo: Revista dos Tribunais. 2002.
} 
obtenção de lucro e fácil enriquecimento ${ }^{5}$. Este tipo de criminalidade demanda a movimentação de vultosas quantias de dinheiro denotando a inserção dos sujeitos ativos tanto no âmbito da criminalidade empresarial privada, quanto na cooptação de agentes públicos, comprometendo, não raras vezes, o próprio sistema político, e repercutindo negativamente nos cofres do Erário ${ }^{6}$. Neste cenário não é incomum verificar-se a prática de condutas que transcendem o âmbito jurídico estritamente nacional ${ }^{7}$, exigindo, por parte dos órgãos de controle a adoção de medidas destinadas a localização e repatriação de ativos alocados no exterior.

Cumpre observar, na maioria das vezes, o produto ilícito e os proveitos auferidos passam por processos de 'reciclagem' destinados a mascarar a origem ilícita da vantagem econômica. Assim sendo, os bens e valores apreendidos no curso das investigações e ações penais, de igual modo, cresceram consideravelmente em número e diversidade. Esta constatação impõe às autoridades públicas uma ampliação na percepção prévia da valoração econômica dos objetos de busca e apreensão, precisamente no âmbito de sua potencial utilidade reditícia (tanto de bens fungíveis, quanto de bens infungíveis), ao mesmo tempo em que o Poder Público é premido por situações fáticas vinculadas à preservação e destinação do patrimônio sob sua guarda. A figura dos pátios de delegacias abarrotados de veículos e outros materiais apreendidos, expostos à intempérie, afronta até mesmo as recomendações práticas do $\mathrm{CNJ}^{8}$.

Em uma década onde fatos atinentes à criminalidade econômico-financeira se tornaram corriqueiros, as medidas assecuratórias assumiram um real protagonismo ${ }^{9}$. A diretriz da politica

\footnotetext{
${ }^{5}$ CORRÊA JUNIOR., Alceu. Confisco Penal: Alternativas á prisão e aplicação aos delitos econômicos. São Paulo: IBCCRIM, 2006. p. 22 e ss.

${ }^{6}$ Conforme a reflexão de PONS, quando lida com a temática da corrupção na sociedade moderna, tais atuações se pautam em um exercício rotineiro da sociedade, onde se valoriza o ter antes do ser, desencadeando um comportamento paulatino na busca por vantagens pessoais. (PONS, Noël. La corruption des elites: expertise, lobbying, conflits d'intérêts. Paris: Odile Jacob. 2012. p. 10 e ss.). Também nessa toada da corrupção e envolvimento de empresas e Poder Público na criminalidade moderna, vide as reflexões de CARVALHOSA, Modesto. Considerações sobre a Lei anticorrupção das pessoas jurídicas: Lei n. 12.846 de 2013. São Paulo: Revista dos Tribunais. 2015. pp. 83-103.

7 FIGUEIREDO DIAS denota, no contexto histórico, o crescente aparecimento dessa nova criminalidade, sendo esta complexa, organizada, por muitas vezes ramificando-se em escala global. (FIGUEIREDO DIAS, Jorge de. Direito penal, parte geral, tomo I: questões fundamentais: a doutrina geral do crime. $1^{\text {a }}$ edição. São Paulo: Revista dos Tribunais. 2007. P. 296.

8 Vide Manual de bens Apreendidos - Corregedoria Nacional de Justiça - CNJ. Disponível em: <http://www.cnj.jus.br/images/corregedoria/MANUAL_DE_GESTO_DOS_BENS_APREENDIDOS_cd.pdf >. Acesso em 07 jul. 2015.

${ }^{9}$ Como ressalta CORRÊA JUNIOR sobre o confisco: "Nesta sociedade de risco, a pena de confisco de bens apresenta-se como medida penal adequada e útil, além de muito eficaz no combate ao lucro ilícito derivado de atividades criminosas" (CORRÊA JUNIOR, Alceu. Op. Cit. p. 24). No mesmo sentido frisa LOPES JR., ao expor: “(...) na última década, com a crescente expansão do direito penal econômico e tributário,
} 
criminal é transparente: objetiva-se a recuperação de ativos provenientes de atividades ilícitas. Essa orientação, como não poderia deixar de ser, acaba permeando as consequências da sentença penal condenatória, notadamente nos crimes de lavagem de dinheiro, a exemplo do que dispõe o artigo $7^{\circ}$, inciso I, da Lei 9.613/98, e o artigo 91, II, do Código Penal. Ambos dispositivos, ao tratar a respeito dos efeitos da condenação, indicam, como resultado direto, o perdimento dos instrumentos e produtos da infração criminal.

Trazendo à baila as reflexões de Hassemer, sempre propícias a demonstrar o agravamento da norma processual penal, é fácil constatar que as reformas legislativas têm se concentrado na fase preliminar investigativa com medidas invasivas aos direitos fundamentais ${ }^{10}$. Essa assertiva de forma idêntica se aplica à norma penal substantiva, ao verificar-se a receptividade acrítica de tipos penais oriundos da contemporaneidade, retratados na proposta de tipificação do enriquecimento ilícito, e no agravamento desmedido da pena no tipo da corrupção, além de outras iniciativas que buscam atender uma suposta tranquilidade social, como ocorre na reivindicação da criminalização de condutas já amparadas na modalidade do injusto penal-tributário.

Significa, enumerando: o tipo penal do enriquecimento ilícito ${ }^{11}$, a diretriz da recuperação de ativos $^{12}$, as medidas governamentais anticorrupção, associado à própria tipificação do crime de lavagem de dinheiro, e o redimensionamento do confisco ${ }^{13}$, são apontados como importantes

as medidas assecuratórias estão na pauta do dia." (LOPES JR., Aury. Direito processual Penal. $9^{\text {a }}$ ed. rev. e atual. São Paulo: Saraiva. 2012. p. 905).

${ }^{10}$ Cite-se, por exemplo, a interceptação telefônica, a escuta ambiental, o emprego de agentes infiltrados e a nova dimens8ão do confisco. Sobre o agravamento da norma penal e processual bem como da alteração do papel do Estado, vide HASSEMER, Winfried. Processo Penal e Direitos Fundamentais. In. Jornadas de Direito Processual Penal e Direitos Fundamentais (Coord. Maria Fernanda Palma). Coimbra: Almedina, 2004. p. 20 e ss.

${ }^{11}$ BOTTINI, Pierpaolo Curz. O Enriquecimento ilícito e a presunção de inocência. In: Revista Consultor Jurídico. Disponível em http://www.conjur.com.br/2012-mai-08/direito-defesa-enriquecimento-ilicitopresuncao-inocencia. Acesso em: 27 de março de 2015.

${ }_{12}$ Sobre a atual política criminal expansiva de recuperação de ativos, SIMÕES, Euclides Damásio; TRINDADE, José Luis F.. Recuperação de Ativos: Da perda ampliada à actio in rem (virtudes e defeitos de remédios para patologias graves). In: Revista Julgar online - 2009. Disponível em: < http://julgar.pt/recuperacoes-de-activos-da-perda-ampliada-a-actio-in-rem/>. Acesso em 25 maio 2015; e, CAEIRO, Pedro. Sentido e função do instituto da perda de vantagens relacionadas com o crime no confronto com outros meios de prevenção da criminalidade reditícia. In: Revista Brasileira de Ciências Criminais. Ano 21. Vol. 100. Jan-fev./2013. No Brasil, vide o artigo de PALUDO, Januário. Recuperação de Bens. In Lavagem de dinheiro - prevenção e controle penal , Carla Veríssimo de. (Coord.). $2^{\mathrm{a}}$ ed. Porto Alegre: Verbo Jurídico. 2013. p. 681.

13 Ver AGUADO CORREAA, Tereza. Decomiso de los productos de La delincuencia organizada "garantizar que El delito no resulte provechoso". In: Revista Eletrônica de Ciência Penal y Criminologia. REPC 15-05 (2013). Disponível em: http://criminet.ugr.es/recpc. Acesso em: 29 de março de 2015; CORRÊA, João 
ISSN 1981-3694

(DOI): $10.5902 / 1981369419655$

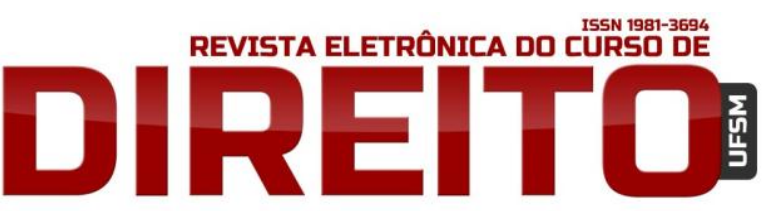

ALIENAÇÃO ANTECIPADA E DESTINAÇÃO PRÉVIA DE BENS CONSTRITOS: LIMITES ÉTICOS E JURÍDICOS NO ÂMBITO DA CRIMINALIDADE ECONÔMICA

frentes de combate à chamada criminalidade econômica. Na prevenção e repressão deste núcleo delitivo, não bastaria imposição de pena privativa, surgindo assim ferramentas penais e processuais penais ora nominadas, pois, conforme a reflexão de Caeiro, a aplicação de medidas que resultem em perda de vantagens deve derivar na assertiva onde o crime não deve compensar ${ }^{14}$.

Os instrumentos de prevenção desta variante delitiva, cujo escopo é o lucro, pois, unidos por um único objetivo: combater o benefício econômico gerado por este tipo de criminalidade ${ }^{15}$. Bem por isso, a criminalização do branqueamento de capitais, o confisco e a recuperação de ativos têm sido elencadas como as principais frentes na luta contra a criminalidade organizada ${ }^{16}$.

Todavia, a recuperação dos ativos desviados não será alcançada de maneira eficaz, ou satisfatória se, ao final da relação processual penal, os bens objeto da pena de confisco forem transferidos para a titularidade do Poder Público com sua projeção econômica desvalorizada. Imagine-se, por exemplo, quando diante de uma condenação criminal pela prática do crime de corrupção (ativa/ passiva), os bens apreendidos inicialmente pelo Poder Público são a ele definitivamente entregues com seu valor venal depreciado, e, seu estado material, objetivamente considerado, depredado, em razão da impossibilidade de acondicionamento adequado nos depósitos públicos. Não se requer esforço teórico para deduzir tal quadro.

Sob este vértice, e sem olvidar a finalidade das medidas cautelares que, sejam patrimoniais ou reais - donde se inserem a alienação antecipada e a destinação prévia dos bens constritos - buscam a garantia da efetividade do provimento jurisdicional, sensato convir, conforme a observação de Alves, que "não basta a certeza de que a sentença virá. Faz-se necessária também a certeza de que virá de forma útil”17.

$\mathrm{Na}$ tentativa de minimizar os prejuízos resultantes da guarda inadequada dos bens apreendidos no curso da persecutio criminis, remontando-se num primeiro momento contra os crimes de tráfico de entorpecentes, a lei 9.804/99 - que alterou a de número 6.368/76 - em seu artigo 34 e parágrafos, trouxe ao ordenamento jurídico pátrio a possibilidade de alienação e afetação provisória dos bens constritos antes mesmo do trânsito em julgado da Ação Penal. Acertadamente Corrêa Junior discorreu sobre esse instrumento como uma modalidade de

Conde. Da Proibição do Confisco à Perda Alargada. Lisboa: INCM - Imprensa Nacional Casa da Moeda: Procuradoria Geral da Repúbica, 2012. No Brasil, CORRÊA JUNIOR, Alceu. Op. Cit.

${ }^{14}$ CAEIRO, Pedro. Op. Cit., pp. 460-461.

${ }^{15}$ AGUADO CORRÊA, Tereza. Op Cit.

${ }^{16}$ Idem.

17 ALVES, Rogério Pacheco. O Poder Geral de Cautela no Processo Penal. In: Revista EMERJ, v. 6, n. 22, 2003, pp. 276-306 
confisco especial de valores e bens relacionados a estes tipos de injusto, representando "um grande avanço na legislação pátria em sintonia com a tendência internacional, uma vez que supera a exigência de ilicitude intrínseca do instrumento do crime para fins de confisco especial"18.

Referida normativa, objetivou preservar-lhes o valor de mercado tal qual à época da apreensão. Citada previsão foi mantida nas posteriores alterações legislativas direcionadas ao tratamento legal da prevenção e repressão dessa modalidade delitiva, culminando nos diversos contornos estabelecidos pelo artigo 62 e $\$ 1^{\circ}$ da Lei $11.343 / 06^{19}$. No tocante à venda antecipada de bens, esta tratativa apresentou-se como matriz do conteúdo normativo incorporado à Lei 9.613/98 em seus artigos $4^{\circ}$, e $4-\mathrm{A}^{20}$, pela Lei $12.683 / 12^{21}$.

Em específico, atinente à alienação antecipada, nada obstante sua consagração como instituto apenas em 2006, mesmo com aplicabilidade restrita às situações delineadas na lei antitóxicos, já em 2005 o ENCCLA (Estratégia Nacional de Combate à Corrupção e à Lavagem de Dinheiro) a indicou, sob o verbete da Meta $n^{\circ} 19$, como medida cautelar apta a instituir um melhor aproveitamento dos bens constritos ${ }^{22}$. Tal enunciado encontrava assentamento nos prejuízos para o Estado, e também para o próprio denunciado, decorrentes da deterioração dos bens e, muitas vezes, sua perda, em virtude dos longos períodos de tempo os quais eram submetidos à custódia do Poder Público, aguardando em precariedade de condições o trânsito em julgado da ação penal.

${ }^{18}$ CORREAA, JUNIOR., Alceu. Op. Cit..p. 180.

${ }^{19}$ Reza o Art. 62 da Lei 11.343/06: "Os veículos, embarcações, aeronaves e quaisquer outros meios de transporte, os maquinários, utensílios, instrumentos e objetos de qualquer natureza, utilizados para a prática dos crimes definidos nesta Lei, após a sua regular apreensão, ficarão sob custódia da autoridade de polícia judiciária, excetuadas as armas, que serão recolhidas na forma de legislação específica. \$ $1^{\circ}$ Comprovado o interesse público na utilização de qualquer dos bens mencionados neste artigo, a autoridade de polícia judiciária poderá deles fazer uso, sob sua responsabilidade e com o objetivo de sua conservação, mediante autorização judicial, ouvido o Ministério Público".

${ }^{20}$ Ao revés da tratativa desde há muito aplicada nas disposições normativas de combate ao tráfico ilícito de estupefacientes, o legislador infraconstitucional, ao dispor sobre os crimes de lavagem de ativos, seja na literatura original da lei $9.613 / 98$, seja após a alteração operada por meio da lei $12.683 / 12$, optou por não incluir a afetação provisória no rol das medidas cautelares passíveis de aplicação no âmbito dos processos que cuidem dos crimes de branqueamento de capitais.

${ }^{21}$ BADARÓ, Gustavo Henrique; BOTTINI, Pierpaolo Cruz. Lavagem de Dinheiro: aspectos penais e processuais penais: comentários à Lei 9.613/98, com as alterações da Lei 12.683/12. São Paulo: Revista dos Tribunais, 2012, p. 283 e 284.

${ }_{22}$ Meta n. 19 ENCCLA - Sugerir aos órgãos do Ministério Público e do Poder Judiciário o melhor aproveitamento dos bens apreendidos, sequestrados, arrestados dentro das possibilidades legais já existentes, inclusive a alienação antecipada, se necessário. 
Percebendo os avanços possibilitados pelo instituto, o CNJ editou a Recomendação n. 30/2010, aconselhando aos magistrados com competência criminal, nos autos onde existam bens apreendidos sujeitos à pena de perdimento, a alienação antecipada de tais, como forma de preservar-lhes o respectivo valor. 0 cerne de nominadas medidas processuais propõe o resguardo, mediato ou imediato, dos interesses do Estado, assim como do próprio investigado/acusado, assegurando-se a preservação do valor patrimonial da res, considerando o poder geral de cautela e, por analogia ${ }^{23}$, o disposto nos artigos. 120 e $\S \S, 122$ e parágrafo único, e 133, do Código de Processo Penal ${ }^{24}$, bem como, o art. 670, do Código de Processo Civil ${ }^{25}$, A novidade propiciada pela referida Recomendação possibilitou a aplicação do instituto também a crimes de outra natureza, sempre que:

(...) se cuide de coisa ou bem apreendido que pela ação do tempo ou qualquer outra circunstância, independentemente das providencias normais de preservação, venha a sofrer depreciação natural ou provocada, ou que por ela venha a perder valor em si, venha a ser depreciada como mercadoria, venha a perder a aptidão funcional ou para o uso adequado, ou que de qualquer modo venha a perder a equivalência com o valor real na data da apreensão. ${ }^{26}$

Ciente da ausência de regulamentação suficiente, seja na Lei de Tóxicos, seja no Código de Processo Penal, a mesma Recomendação previa a aplicação subsidiária das normas do processo civil incidentes sobre a execução por quantia certa, no que respeita à avaliação (art.

\footnotetext{
${ }^{23}$ ALEIXO, Márcia Lúcia Clemente Neto. Alienação antecipada de bens e valores no crime de "lavagem de dinheiro" e o devido processo penal. In Anais do XVII Congresso Nacional do CONPEDI, Brasília, Novembro de 2008. p. 3035.

${ }^{24}$ Importante a referência analógica, pois o Código de Processo Penal sempre trouxe a possibilidade de alienar-se antecipadamente os bens tornados indisponíveis sujeitos à deterioração. Entretanto, tal disposição consta do \$5, do artigo 120, do Códex processual criminal, sob o título específico "Das Provas", e se refere às situações específicas daqueles bens já compreendidos pelo juízo como desnecessários a título de material probatório ou dispensáveis para fins de indenização à vítima do delito, oportunidade em que, quando no momento da restituição pairar dúvida acerca da titularidade do bem, e se tratar o móvel ou imóvel de coisa facilmente deteriorável ou perecível, determinará, o magistrado, sua avaliação e venda em leilão público, "depositando-se em juízo o valor apurado até que se defina quem é o legítimo dono". Nesse sentido, JR., Aury Lopes. Op. Cit., p. 725

${ }^{25}$ Art. 670. O juiz autorizará a alienação antecipada dos bens penhorados quando: I - sujeitos a deterioração ou depreciação; II - houver manifesta vantagem. Parágrafo único. Quando uma das partes requerer a alienação antecipada dos bens penhorados, o juiz ouvirá sempre a outra antes de decidir.

26 Recomendação $n^{\circ}$ 30/2010, inciso I, "b": ordenem, em cada caso e justificadamente, a alienação antecipada da coisa ou bem apreendido para preservar-lhe o respectivo valor, quando se cuide de coisa ou bem apreendido que pela ação do tempo ou qualquer outra circunstância, independentemente das providencias normais de preservação, venha a sofrer depreciação natural ou provocada, ou que por ela venha a perder valor em si, venha a ser depreciada como mercadoria, venha a perder a aptidão funcional ou para o uso adequado, ou que de qualquer modo venha a perder a equivalência com o valor real na data da apreensão;
} 
680, CPC), licitação (art. 685-A, CPC) e adjudicação ou arrematação de bens (art. 686 e ss., CPC).

Na seara administrativa, a temática foi devidamente apreciada, sendo regulamentada pela Receita Federal, por meio da Portaria 3.010/2011 ${ }^{27}$, prevendo, em linhas gerais, a possibilidade destinação, pelo órgão, de mercadorias custodiadas, mesmo em processos que ainda não alcançaram o trânsito em julgado. A principal preocupação encontrava respaldo na proteção patrimonial e na abreviação do tempo de permanência destes bens em depósitos, diminuindo assim, os custos com controles e armazenagem evitando a depreciação dos bens ${ }^{28}$.

Atento às transformações que permeavam a realidade forense, em 2011 o Conselho Nacional de Justiça publicou o Manual de Bens Apreendidos, orientando e estimulando os magistrados a uma melhor forma de gestão e destinação dos bens constritos judicialmente em meio a Ações Penais sobre crimes patrimoniais das mais diversas naturezas ${ }^{29}$, citando, dentre eles, a alienação antecipada de bens, conceituada neste expediente como " $a$ venda do bem apreendido em leilão mesmo antes do término da ação penal". No ano seguinte, o instituto da alienação antecipada foi adicionado ao texto da Lei de "Lavagem" de dinheiro por meio da alteração operada pela Lei 12.683/12, onde obteve peculiar atenção do legislador.

Na sequência, acrescentou-se a Lei 12.694/12, que, de forma expressa, incluiu o instituto da alienação antecipada de bens no códex processual criminal (art.144-A), constituindo verdadeiro respaldo às normativas anteriores. Com a inserção deste dispositivo no corpo da legislação codificada, as incertezas quanto à aplicabilidade da venda antecipada de bens em processos que extravasam o âmbito de incidência das Leis 9.613/98 e 11.343/06, foram dirimidas, certificando a legitimidade dos provimentos judiciais anteriores, os quais, cientes do

27 Portaria 3.010/2011 - Art. $3^{\circ}$ A destinação de mercadorias sob custódia visa alcançar, mais rapidamente, benefícios administrativos, em especial agilizar o fluxo de saída e abreviar o tempo de permanência em depósitos, de forma a disponibilizar espaços para novas apreensões, diminuir os custos com controles e armazenagem e também a evitar a obsolescência e a depreciação dos bens.

${ }^{28}$ Art. $1^{\circ}$ da Portaria 3.010/2011. Conforme dados da época em que foi editada a normativa, apresentados pelo Sistema Nacional de Bens Apreendidos, existiam, sob responsabilidade do Poder Judiciário, bens totalizando a monta de R\$2,1 bilhões (\%93,3 do total apreendido desde a implementação do banco de dados em 2009), os quais não foram restituídos a seus antigos proprietários ou alienados pela Justiça. (http://www.conjur.com.br/2011-ago-24/manual-cnj-ajudara-juiz-vender-bens-apreendidos. Acesso em 02 jun. 2015).

${ }^{29}$ Tal qual apontado por Vladimir Passos DE FREITAS, em entrevista ao Conjur, a normativa foi editada com o objetivo de atender ao princípio constitucional da eficiência, exaltado no art. 37 da Constituição Federal (http://www.conjur.com.br/2011-out-15/manual-cnj-explica-juizes-bens-apreendidos. Acesso em 06 maio 2015). 
forte viés garantista do instituto, promoviam sua aplicação com fulcro na analogia e no poder geral de cautela ${ }^{30}$.

De fato, as medidas cautelares de indisponibilidade, donde se incluem a alienação antecipada e a destinação prévia de bens constritos, de modo geral, se apresentam como instrumentos aptos a fazer frente à criminalidade reditícia, funcionando como fator de prevenção geral ao desestimular a prática dos crimes albergados neste contexto ${ }^{31}$. 0 recrudescimento das disposições normativas concernentes a esta matéria, resultante desta atual expansão da política criminal de recuperação de ativos, entretanto, não pode passar ao largo de uma análise pormenorizada de suas finalidades e implicações na esfera das garantias processuais e direitos fundamentais dos indivíduos sujeitados ao processo penal ${ }^{32}$.

A eficácia dos instrumentos de recuperação de ativos sempre deverá ser concebida sob a premissa da impossibilidade de flexibilização dos princípios constitucionais de garantia, a exemplo da ampla defesa e da presunção de inocência.

\section{NATUREZA JURÍDICA DO INSTITUTO DA ALIENAÇÃO ANTECIPADA E REGULAMENTAÇÃO NORMATIVA.}

Alicerce de inúmeros provimentos judiciais, fato que se observa da própria Recomendação $n^{\circ}$ 30/2010, do Conselho Nacional de Justiça, com o advento da Lei 12.683/12, a alienação antecipada finalmente encontrou positivação legal quanto aos crimes de lavagem de

\footnotetext{
30 Inclui-se, ainda, neste tópico a recente proposta legislativa compondo as providências do recém publicado "pacote anticorrupção", onde consta o Projeto de Lei $n^{\circ}$ 2.902/11, o qual propõe a reformulação do Capítulo VI do Código de Processo Penal, que, pela redação desta proposta legislativa, passará a denominar-se "DA MEDIDA CAUTELAR DE INDISPONIBILIDADE". Dentre as alterações propostas observa-se a aplicação da alienação antecipada de bens como regra, e não exceção, assim como a inclusão da figura do administrador judicial - novidade no âmbito do CPP, embora já existente na legislação brasileira e de larga aplicação na prática forense -, conferindo-se um minucioso tratamento quanto ao procedimento das mencionadas "medidas cautelares de indisponibilidade".

${ }^{31}$ CAEIRO, Pedro. Op. Cit. pp. 462-463.

$32 \mathrm{Em}$ uma crítica aos procedimentos in rem, CAEIRO denota justamente as fortes características jurídicopenais de tais medidas, embora originariamente não tenham tal natureza, criando-se um risco de, por um lado, utilizar-se de institutos tipicamente penais e processuais penais, e por outro, não levar em consideração todos os princípios e garantias individuais inerentes a tais esferas. Cite-se: "os procedimentos in rem para o confisco de bens de origem ilícita não conseguem libertar-se da sombra jurídico-penal que constantemente os persegue, e deixam a indelével impressão de expedientes manobrados pelo Estado para subverter os princípios e mecanismos do direito penal." (CAEIRO, Pedro. Op. Cit. p. 479).
} 
dinheiro, afastando a necessidade de uma aplicação pautada, principalmente, na analogia ${ }^{33}$ e no abstrato e controvertido poder geral de cautela ${ }^{34}$. Relevante mencionar, desde a metade da década de 90, na chamada "Operação Descobrimento da América", o instituto da venda prévia de bens foi largamente utilizado. Desde então houve uma progressão no uso de tais mecanismos, revelando-se mister uma análise acerca de seu perfil jurídico e ético.

A alienação antecipada de bens, assim como a destinação prévia, constitui provimento de natureza cautelar real, o qual, sucedendo outras medidas de mesma natureza, converge para a preservação do resultado patrimonial útil de eventual sentença penal condenatória.

As dificuldades encontradas pelos órgãos do poder público em acondicionar provisoriamente em sua estrutura bens de propriedade alheia (seja do investigado, do denunciado e de terceiros relacionados à investigação ou a ação penal), arcando com todos os cuidados inerentes à condição de depositário de bens cuja titularidade e natureza, se lícita ou ilícita, ainda se encontra sob discussão judicial, em processo orientado pelo princípio do in dubio pro reo. A problemática da destinação dos bens constritos durante a persecução penal não é ignorada pela comunidade jurídica ${ }^{35}$. Todavia, trata-se de uma árida questão inerente às medidas cautelares reais.

Desde a criação do Código de Processo Penal e, em especial, das providências assecuratórias, a preocupação legislativa restringiu-se à previsão das hipóteses de permissão legal para tornar indisponíveis determinados bens do investigado, ou acusado, por crimes

\footnotetext{
${ }^{33} \mathrm{~A}$ princípio, dada a inexistente normativa penal a respeito, aqueles que consideravam a possibilidade de interpretação analógica à lei processual penal (art. $3^{\circ}$, do CPP), rememoravam as inúmeras disposições do Código Civil e de sua lei processual adjetiva que autorizam a alienação antecipada de bens penhorados quando sujeitos à deterioração ou depreciação, ou, ainda, quando houver manifesta vantagem (art. 670, do CPC).

${ }^{34}$ Consignando a crítica de parcela significativa da doutrina especializada em face à aplicação do poder geral de cautela no âmbito do Processo Penal, cite-se ACCIOLY, Maria Francisca dos Santos. As medidas cautelares patrimoniais na lei de lavagem de dinheiro. Rio de Janeiro: Lumen Juris, 2014, p. 57. Mencionada autora registra a incompatibilidade de referido instituto com as bases de um processo penal centrado num Estado Democrático de Direito, precisamente por contrariar o princípio da legalidade nos pontos em que este se faz mais determinante: na taxatividade dos mecanismos de restrição dos direitos e garantias constitucionais.

${ }^{35}$ Sobre essa problemática vide DE OLIVIERA, Marcelo Ribeiro. Provimentos Cautelares Patrimoniais em Lavagem de ativos. In: Lavagem de dinheiro - prevenção e controle penal, Carla Veríssimo de. (Coord.). $2^{\mathrm{a}}$ ed. Porto Alegre: Editora Verbo Jurídico, 2013, p. 670 e ss.; PALUDO, Januário. Op. Cit., p. 686 e ss; TUMA JÚNIOR, Romeu. Combate à lavagem de dinheiro e corrupção - Os frutos da parceria entre o Ministério da Justiça, a Advocacia-Geral da União e outros órgãos do Estado brasileiro. In: Debates em Direito Público, Belo Horizonte, Ano 8, n. 8, Out. 2009. Disponível em: <http://bid.editoraforum.com.br/bid/PDlexibepdf.aspx?tipoConteudo=Normal\&vw=S\&pdiCntd=72408\&idP ublicacao=30>. Acesso em 03 jun. 2015; BADARÓ, Gustavo Henrique; BOTTINI, Pierpaolo Cruz. Op. Cit.,. pp. 301-302; DE CARLI, Carla Veríssimo. Lavagem de Dinheiro: ideologia da criminalização e Análise do discurso. 2 ed. Porto Alegre: Verbo Jurídico, 2012, pp. 222-224.
} 
patrimoniais quando interessasse à persecução criminal. Em contrapartida, deixou-se de lado a discussão inerente aos necessários cuidados a serem despendidos relativamente ao próprio bem arrecadado, o qual passou a ser confinado em salas vazias de delegacias e fóruns e em pátios abertos, onde era submetido ao desgaste ocasionado pelas intempéries.

Com efeito, o que a princípio, e apenas aparentemente, não se revelou um inconveniente, dada a quantidade ínfima de bens apreendidos e, porque não, de seu baixo valor de mercado, passou a representar uma clara necessidade de reformulação destas práticas. Isso ocorreu em função do crescente abarrotamento de salas de delegacias e fóruns com as apreensões, bem como o rol de bens tornados indisponíveis ao investigado/acusado, pois transmitidos à tutela provisória do Poder Público, passou a incluir, e.g., aeronaves, automóveis luxuosos e obras de $\operatorname{arte}^{36}$, patrimônio este que demanda cuidado diferenciado para sua preservação, além de espaços físicos, em regra, muito mais amplos.

Ponto de divergência, digno de nota, refere-se a um apontado óbice à aplicação da alienação antecipada, em virtude de sua aparente contraposição ao princípio da não culpabilidade, ou in dubio pro reo, ao argumento no qual a disposição dos bens do acusado antes da certeza sobre sua responsabilidade penal constituiria inaceitável antecipação dos efeitos da condenação ${ }^{37}$.

Nessa toada argumentativa, o núcleo essencial da alienação antecipada aponta para uma finalidade de proteção dos interesses do próprio sujeito que teve decretada a indisponibilidade de seus bens e, por via reflexa, dos interesses do Estado, embora forçoso admitir a agressividade da medida que, ao revés dos demais instrumentos assecuratórios, além de retirar do sujeito a posse imediata sobre o bem, afasta-lhe da possibilidade de retomá-lo na hipótese de uma sentença absolutória.

Sob outro vértice, não se discute que a exposição dos bens constritos a condições favoráveis a uma significativa diminuição em sua projeção de mercado constitui violação direta ao direito fundamental que o individuo possui à propriedade (art. $5^{\circ}$, inciso XXII, da CF). Analisando-se tal afirmação, ainda é necessário ponderar que o interesse público não pode

\footnotetext{
${ }^{36}$ Situações recentes que ressaltam bem este quadro são os casos dos aviões da VASP, em seu processo de falência; do traficante colombiano Juan Carlos Ramirez Abadia, cuja extensa coleção de objetos de luxo incluíam carros, roupas, acessórios etc.; as obras de arte apreendidas no curso das investigações do escândalo envolvendo a Petrobrás; entre outros. Estes cenários tornam transparente o novo quadro de apreensões que se realizam pelo Poder Público, exigindo novas ações para sua custódia e preservação.

${ }^{3}$ LEITE, Larissa. Medidas patrimoniais de urgência no processo penal - implicações teóricas e práticas. Rio de Janeiro: Renovar, 2011, p. 196. Também em sentido crítico e antes do advento da Lei 12.683/12, vide ALEIXO, Márcia Lúcia Clemente Neto. Op. Cit. p. 3045-3046.
} 
sobrepujar e escusar a degradação econômica do patrimônio do sujeito que sequer teve sua culpabilidade comprovada mediante sentença penal transitada em julgado, após observado o devido processo penal, do qual poderá advir provimento absolutório ${ }^{38}$.

Melhor solução, pois, ao impasse entre o interesse público - provimento cautelar de constrição dos bens como garantia à efetividade do provimento jurisdicional final - e o interesse do titular dos bens apreendidos, nos parece ser a alienação antecipada, que permite a garantia de preservação do valor venal dos bens móveis e imóveis correspondentes à época de sua apreensão, acrescidos de correção monetária. Justamente por isso andou bem o legislador ao imprimir certa nota de amplitude à redação do $\$ 1^{\circ}$, do artigo $4^{\circ}$, da Lei $9.613 / 98$, determinando cabível a alienação antecipada para a preservação dos bens que estiverem sujeitos "a qualquer grau" de deterioração ou depreciação ${ }^{39}$.

A aplicação das medidas cautelares reais deve acarretar resultados eficazes, sem, contudo, desrespeitar as garantias inerentes ao devido processo legal ${ }^{40}$. Por conseguinte, uma eficiente forma de garantir a conservação dos bens constritos e a higidez do direito fundamental ao patrimônio do sujeito, assim como a efetividade do provimento judicial, seja condenatório donde resultará a pena de confisco dos bens e valores nos termos do artigo $7^{\circ}$, da Lei 9.613/98 seja absolutório - onde os valores provenientes da alienação, e que foram mantidos em depósito, serão devolvidos devidamente atualizados e corrigidos monetariamente (art. $4^{\circ}-\mathrm{A}, \$ 5^{\circ}$ incisos I e II da Lei 9.613/98) -, é proceder-se à alienação antecipada dos bens objeto de medidas assecuratórias anteriormente decretadas.

Para além dos atributos gerais das medidas cautelares patrimoniais, a destinação prévia de bens constritos pode ser singularizada por seu caráter "sucessório". É dizer, trata-se de medida cabível somente após a implementação de outra medida cautelar patrimonial; colocado de outra forma, somente há que se falar em alienação antecipada, ou destinação provisória, de bens objeto de apreensão, sequestro ou arresto (previstas no Título VI, Capítulo VI do Código de Processo Penal pátrio).

\footnotetext{
${ }^{38}$ Importante trazer a baila as reflexões de CAEIRO sobre as implicações (em sede de direito comparado) dos procedimentos in rem, quando do conflito entre interesse estatal e do jurisdicionado, bem como a problemática quanto a não imputação de culpa no deslinde de tais expedientes, em face de possíveis provas produzidas em desfavor do imputado. (CAEIRO, Pedro. Op. Cit. pp. 475-478).

${ }^{39}$ Necessário constar as críticas de parte da doutrina à amplitude de tais termos, atentando para a necessidade de interpretação restritiva à narrativa "qualquer grau de deterioração ou depreciação", pois de outro modo estar-se-ia possibilitando a venda antecipada de "praticamente qualquer bem constrito (...) em uma desproporcional e injustificada restrição ao direito de propriedade de alguém que ainda é presumido inocente". BADARÓ, Gustavo Henrique; BOTTINI, Pierpaolo Cruz. Op. Cit. p. 301-302

${ }^{40}$ LOPES JR., Aury. Op. Cit. p. 907.
} 
Em específico quando ao objeto da alienação antecipada, esta poderá recair sobre todos os bens apreendidos no curso da persecutio criminis, desde que, possuindo significativo conteúdo econômico, estejam sujeitos a qualquer grau de deterioração ou em dificuldade de manutenção. Não apenas isto, melhor interpretação conduz ao entendimento de que "não apenas os bens sujeitos à deterioração imediata devem ser alienados, mas todos aqueles que correm o risco evidente de perderem sua relevância patrimonial" ${ }^{41}$.

Diversamente da norma contida no artigo 62 da normativa de tóxicos, Lei 11.343/06, cuja redação literal é expressa em admitir a alienação antecipada somente àqueles bens utilizados como instrumentos dos crimes previstos naquela lei, uma leitura sistemática do artigo $4^{\circ}$, caput, e seu $\$ 1^{\circ}$, da Lei 9.613/98 revela cabível a venda cautelar de quaisquer bens constritos no decorrer da persecução penal, independente da modalidade do expediente assecuratório que deu ensejo à determinação de sua indisponibilidade.

Com efeito, diante da expressa previsão na Lei de Lavagem de Dinheiro, onde as medidas assecuratórias ali referenciadas terão por finalidade assegurar a perda de todos os bens e valores relacionados direta ou indiretamente à prática dos crimes sob apreciação como efeito da condenação (art. 91, II, do CP e art. $7^{\circ}$, I, da Lei 9.613/98), assim como o ressarcimento dos danos provenientes da prática delitiva, pode-se dizer que as medidas assecuratórias previstas no Código de Processo Penal são admissíveis também no âmbito da Lei 9.613/98. Nesta medida, serão passíveis de alienação antecipada todos aqueles bens, móveis ou imóveis, de proveniência lícita ou ilícita, sujeitos à busca e apreensão, sequestro, arresto, especialização e registro da hipoteca legal, sejam eles instrumentos, produto ou proventos do crime de lavagem de dinheiro, ou, até mesmo, da infração penal antecedente. Quanto a esta última, exsurge clara a insegurança jurídica trazida pela desnecessidade de comprovação da infração antecedente, ponto já há muito combatido pela doutrina ${ }^{42}$.

A expressão cunhada pelo legislador "medidas assecuratórias de bens, direitos e valores do investigado ou acusado, ou existentes em nome de interpostas pessoas, que sejam

\footnotetext{
${ }^{41}$ DE OLIVIERA, Marcelo Ribeiro. Provimentos Cautelares Patrimoniais em Lavagem de ativos. In Lavagem de dinheiro - prevenção e controle penal, Carla Veríssimo de. (Coord.). $2^{\mathrm{a}}$ ed. Porto Alegre: Verbo Jurídico, 2013, p. 670.

${ }^{42}$ Neste sentido, anotem-se as discussões doutrinárias acerca da natureza da prova da infração penal antecedente suficiente à condenação pelo crime de lavagem de dinheiro. Onde alguns argumentam pela viabilidade das provas indiretas, meramente circunstanciais, outros arguem a imperiosa necessidade de um arcabouço probatório preciso. A respeito, veja-se: PITOMBO, Antônio Sérgio A. de Moraes. Lavagem de Dinheiro: A tipicidade do crime antecedente. São Paulo: RT, 2013; CALLEGARI, André Luís. Direito Penal Econômico e Lavagem de Dinheiro - aspectos criminológicos. Porto Alegre: Livraria do Advogado, 2003.
} 
instrumento, produto ou proveito dos crimes previstos nesta lei ou das infrações penais antecedentes", aliado ao conteúdo do $\$ 4^{\circ}$, do artigo $4^{\circ}$, que prevê a possibilidade de decretação da medida assecuratória para salvaguardar a reparação do dano decorrente da lavagem de dinheiro ou da infração penal antecedente, permite-nos afirmar: tanto bens de origem lícita quanto ilícita poderão ser alienados antecipadamente ${ }^{43}$, caso comprovadamente sujeitos a qualquer grau de deterioração ou depreciação, ou quando houver dificuldade para sua manutenção ${ }^{44}$, e, ainda mais, que tal medida, ao menos a princípio, poderá ser tomada em qualquer fase da persecutio criminis, seja durante a investigação preliminar, seja no decorrer da ação penal, haja vista lacuna legislativa neste ponto ${ }^{45}$.

\section{PROCEDIMENTO, EFETIVIDADE E DESTINAÇÃO PRÉVIA.}

Consoante o regramento disposto na Lei 9.613/98, a alienação antecipada deverá ser requerida mediante petição autônoma, autuada em apartado e com tramitação em separado em relação ao processo principal (art. 4-A, caput), podendo ser requerida pelo Ministério Público, solicitada pela "parte interessada", ou determinada de ofício pelo magistrado ${ }^{46}$. A gama de postulantes é a mais ampla possível. Neste tópico, importante referenciar Bottini e Badaró, quando esclarecem que "parte interessada" poderá referir-se ao próprio acusado, ou eventualmente investigado, ao ofendido porventura requerente da medida cautelar real a qual resultou na constrição do patrimônio sob tutela estatal, ou até mesmo ao terceiro em nome de quem o bem está vinculado, sob fundamento de tratar-se de bem “existente em nome de

\footnotetext{
43 BADARÓ, Gustavo Henrique; BOTTINI, Pierpaolo Cruz. Op. Cit. 284.

${ }^{44}$ Art. $4^{\circ} \mathrm{O}$ juiz, de ofício, a requerimento do Ministério Público ou mediante representação do delegado de polícia, ouvido o Ministério Público em 24 (vinte e quatro) horas, havendo indícios suficientes de infração penal, poderá decretar medidas assecuratórias de bens, direitos ou valores do investigado ou acusado, ou existentes em nome de interpostas pessoas, que sejam instrumento, produto ou proveito dos crimes previstos nesta Lei ou das infrações penais antecedentes. (Redação dada pela Lei $\mathrm{n}^{\circ} 12.683$, de 2012)

\$ 10 Proceder-se-á à alienação antecipada para preservação do valor dos bens sempre que estiverem sujeitos a qualquer grau de deterioração ou depreciação, ou quando houver dificuldade para sua manutenção.

${ }^{45}$ Neste ínterim, necessário observar que o legislador da lei 11.343/06 definiu expressamente no $\$ 4^{\circ}$, do artigo 62, que a alienação antecipada processada no rito dos crimes da lei de drogas somente poderá ser requerida e levada a efeito "após a instauração da competente ação penal".

${ }^{46}$ Quanto a decretação de oficio na decretação de medidas assecuratórias por parte do Magistrado, vide a posição contrária de PACELLI, Eugenio. Curso de Processo Penal. $17^{\mathrm{a}}$ ed. rev. e a amp. Atual. São Paulo: Atlas, 2013, p. 7.
} 
interposta pessoa" ${ }^{\text {"47. Ressalte-se que não é incomum o uso de terceiros almejando burlar os }}$ órgãos de controle, por exemplo, buscando legitimar a propriedade de um bem ou aparentar lícita a origem de capitais ora submetidos a medidas assecuratórias.

Os parágrafos do artigo 4-A da Lei 9.613/98 descrevem minuciosamente o procedimento a ser observado para avaliação, leilão e destinação dos bens objeto da alienação prévia. Complementarmente, possível indicar também o regramento posto na Portaria n. ${ }^{\circ} 3.010 / 2011$.

Sem olvidar a ausência de previsão normativa a respeito do momento processual ou extraprocessual apropriado para a requisição da medida, outro fator indica a possibilidade de cabimento da alienação antecipada ainda no decorrer da investigação preliminar. Ora, estando tal expediente vinculado à medida assecuratória que originou constrição do bem, e sendo o sequestro e a busca e apreensão cabíveis já na primeira fase da persecução, em tese, poderia se admitir a alienação antecipada mesmo antes de oferecida a denúncia, tão logo constatada a dificuldade para manutenção ou a sujeição dos bens a qualquer grau de deterioração ou depreciação (art. $4^{\circ}, \S 1^{\circ}$, Lei 9.613/98) $)^{48}$.

Nesta hipótese, porém, ao se fazer valer da alienação antecipada dos bens constritos estar-se-ia afastando-se diametralmente da garantia de proteção ao direito fundamental ao patrimônio do investigado, desvirtuando as finalidades do instituto ao impor ao sujeito ônus incompatível com a situação de investigado ${ }^{49}$. Uma vez que inexistem os indícios suficientes de autoria e materialidade delitiva aptos a possibilitar o oferecimento da denúncia, não há que se falar em fumus boni iuris - ou fumus comissi delicti, aparência do fato delituoso, como define

\footnotetext{
${ }^{47}$ BADARÓ, Gustavo Henrique; BOTTINI, Pierpaolo Cruz. Op. Cit. p. 329-330.

48 Contrariamente a essa possibilidade, BADARÓ e BOTTINI afirmam que "capitulada medida seria desproporcional e injustificada restrição ao direito de propriedade de alguém que ainda é presumido inocente [...]", onde "[...] uma depreciação normal pelo tempo, que não leve a relevante depreciação do valor, não autoriza a alienação antecipada". Em outras palavras, admitir a aplicação da alienação antecipada somente com exame restritivo dos critérios legais é exercício desmedido no instrumento legal. (BADARÓ, Gustavo Henrique; BOTTINI, Pierpaolo Cruz. Op. Cit. p. 302.

${ }^{49}$ Quando se analisa tal instituto sob a ótica da investigação preliminar, é necessário ressaltar justamente o caráter de "filtro" que tal fase processual assume, pois busca apurar a existência ou não dos primeiros indícios de autoria e fumus comissi delicti, em um juízo preliminar antes de se iniciar, efetivamente, o processo penal (LOPES JR., Aury; GLOECKNER, Ricardo Jacobsen. Investigação Preliminar no Processo Penal. $5^{a}$ ed. rev., atual. e ampl. São Paulo: Saraiva, 2013, p. 71 e ss. E p. 428 e ss). Destarte, como colocam LOPES JR. E GLOECKNER, é sabido que o grau de fumus comissi delicti necessário para iniciar uma investigação preliminar e para admissão da acusação são distintos (Idem, p. 429), portanto mesma lógica deve incidir no momento de estabelecer medidas cautelares reais, em especial À alienação antecipada. Importante também referenciar a assertiva de LOPES JR. em outra obra, quando explana: "Daí por que toda cautela é necessária no momento de utilizar as medidas assecuratórias, sublinhando-se a importância de prova de fumus commissi delicti e do periculum in mora, e não se admitindo presunções contra o réu" (LOPES JR., Aury. Op. Cit. p. 920).
} 
doutrina processualista moderna ${ }^{50}$ - que permita verdadeira declaração de perdimento de bens, dada a irreversibilidade da medida ${ }^{51}$, mesmo que garantido o depósito do valor correspondente a ser oportunamente devolvido nos casos de arquivamento do procedimento administrativo de investigação, ou de sentença absolutória.

Nesse sentido, recente decisão proferida pelo Tribunal Regional Federal da $3^{a}$ Região onde - mesmo antes da entrada em vigor das alterações promovidas pela Lei 12.683/12, quando a jurisprudência aplicava a alienação antecipada mediante interpretação analógica - entendeu pela impossibilidade da venda cautelar dos bens constritos antes do término do inquérito policial, na Apelação criminal nº011083-55. 2008.4.03.6000/MS.

Sob outro vértice, uma vez oferecida a denúncia e encontrando-se os bens indisponíveis já por relevante lapso temporal desde as investigações, a verificação da conveniência ou não da alienação deverá ser realizada a partir dos dados concretos de cada situação, apurando-se a natureza dos bens apreendidos, eventual dificuldade de manutenção e comprovada propensão à deterioração ou depreciação, pois, uma vez reconhecida a justa causa para o início da ação penal, tal medida não se revelaria desproporcional, senão adequada à proteção eficiente do direito à propriedade do acusado.

Em face de tal contexto, permanece a reflexão acerca dos requisitos demandados para a decretação da alienação antecipada. Tal provimento cautelar, ao ser assim definido, exigiria ao menos a observância das duas condições necessárias à determinação de qualquer outra medida assecuratória, a saber, a observância do fumus boni iuris - ou fumus comissi delicti - e o periculum in mora ${ }^{52}$. Tratando-se de provimento cautelar sucedâneo de outra medida patrimonial de urgência, é de a constatação da presença de tais elementos anteriormente, mesmo que de forma não exauriente, na prestação jurisdicional antecedente. Desta feita, de seu caráter sucessivo decorre que - a justificar a aplicação da medida ora em comento - o órgão acusatório deverá produzir provas não apenas da materialidade delitiva e dos indícios suficientes da autoria, senão também, da “dificuldade de manutenção do bem”, ou, “de sua sujeição a qualquer grau de deterioração ou depreciação", justificando, pois, a imprescindibilidade da medida $^{53}$.

\footnotetext{
${ }^{50}$ Sobre os requisitos legais exigidos à aplicação das medidas cautelares no processo penal, vide OLIVEIRA, Eugenio Pacelli. Op. Cit; e LOPES JR., Aury. Direito Processual Penal. $9^{\text {a }}$ ed. rev. e atual. São Paulo: Saraiva, 2012.

${ }^{51}$ BADARÓ, Gustavo Henrique; BOTTINI, Pierpaolo Cruz. Op. Cit. 330

${ }^{52}$ LOPES Jr., Aury. Op. Cit. p. 907.

53 Ibidem. p. 919.
} 
ISSN 1981-3694

(DOI): $10.5902 / 1981369419655$

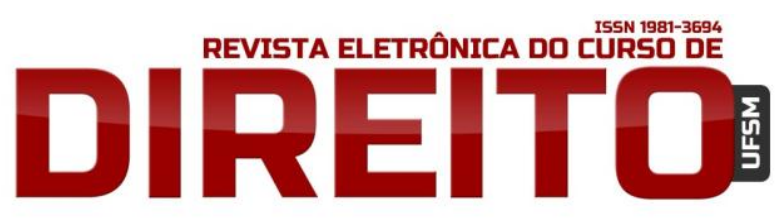

ALIENAÇÃO ANTECIPADA E DESTINAÇÃO PRÉVIA DE BENS CONSTRITOS: LIMITES ÉTICOS E JURÍDICOS NO ÂMBITO DA CRIMINALIDADE ECONÔMICA

Como suplente das medidas de apreensão, eventual liberação de bens, direito ou valores aos quais tenha sido dada destinação provisória somente poderá ocorrer "se comprovada a origem lícita do bem". Tal constatação levou alguns doutrinadores a mencionar sobre a instituição de uma "inversão do ônus da prova"54. Não quer parecer, porém, ter o legislador inovado em matéria de Standards probatórios. O que ocorre, simplesmente, é a possibilidade de determinações cautelares com fulcro nos indícios da proveniência ilícita da res $^{55}$.

Em suma, para se decretar uma medida cautelar de alienação antecipada há de se aferir a presença dos seus requisitos autorizadores a partir da riqueza dos elementos do caso concreto. Mesmo assim, é expediente que requer redobrada cautela ${ }^{56}$. Se por um lado, como defendem alguns, há um menor rigor cognitivo para decretação de medidas patrimoniais, em oposição às medidas pessoais ${ }^{57}$, por outro, há de ser perquirido sempre o standard da necessidade, com busca da menor restrição possível e meio idôneo, conjuntamente à máxima efetividade da relação processual penal, ou seu resultado útil, ao menos do ponto de vista patrimonial, sobretudo diante da tensão jurídica entre o imperativo da resposta estatal aos fenômenos criminais e a presunção de não culpabilidade.

Requerida a venda assecuratória, o juiz determinará a avaliação dos bens e a intimação do Ministério Público para se manifestar acerca da conveniência da medida, caso não tenha sido requerida pelo próprio órgão ministerial (art. 4-A, \$2). Realizado o laudo, este será apresentado às partes, sendo passível de impugnação por essas. Inexistentes ou superadas as divergências acerca dos valores estipulados, o laudo será homologado por sentença, sendo, após, remetidos os bens para venda em leilão ou pregão, preferencialmente eletrônico, onde não poderão ser alienados por preço inferior a $75 \%$ ao valor da avaliação.

As regras sob as quais o leilão deverá ser levado a efeito não são especificadas em nenhum dos diplomas em que a alienação antecipada é prevista (art. 144-A, do CPP, art. 62, da Lei 11.343/06 e art. 4-A d Lei 9.613/98). Isto posto, com o fito de sanar tais omissões e direcionar o judiciário na efetividade do instituto, a Recomendação n. 30 de 2010 do Conselho Nacional de Justiça orientou recorrer-se à legislação processual civil no que tange às regras para a execução por quantia certa quando da avaliação, licitação e adjudicação ou arrematação de

\footnotetext{
${ }^{54}$ DE CARLI, Carla Veríssimo. Op. Cit. p. 221; BADARÓ, Gustavo Henrique, BOTTINI, Pierpaolo Cruz. Op. Cit. pp. 302-305.

${ }^{55}$ BADARÓ, Gustavo Henrique; BOTTINI, Pierpaolo Cruz. Op. Cit.. 299

${ }^{56}$ BARROS, Marco Antônio de. Lavagem de capitais e obrigações civis correlatas: com comentários, artigo por artigo, à lei 9.613/1998. $4^{\mathrm{a}}$ ed. rev., atual., e ampl. São Paulo: Revista dos Tribunais, 2013.

${ }^{57}$ POLASTRI, Marcellus. A tutela cautelar no processo penal. $3^{\text {a }}$ ed. São Paulo: Atlas, 2014, p. 29-30
} 
ISSN 1981-3694

(DOI): $10.5902 / 1981369419655$

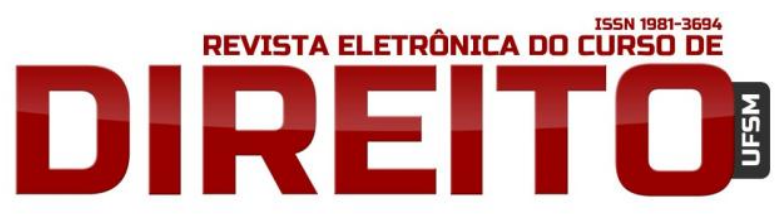

ALIENAÇÃO ANTECIPADA E DESTINAÇÃO PRÉVIA DE BENS CONSTRITOS: LIMITES ÉTICOS E JURÍDICOS NO ÂMBITO DA CRIMINALIDADE ECONÔMICA

bens, não se olvidando das disposições da norma civil constantes do artigo 686, inciso VI, §§2 ${ }^{\circ} \mathrm{e}$ $3^{\circ}$, do Código de Processo Civil, a qual trata da alienação em hasta pública.

De todo modo, o momento cabível à impugnação da alienação antecipada será na fase do $\$ 2^{\circ}$, do art. 4-A, onde, uma vez requerida a medida, o julgador intimará as partes a se manifestarem a respeito e, após isto, no momento de impugnação aos valores constantes no auto de avaliação.

A doutrina diverge quanto ao recurso cabível em face da sentença que decretou a alienação antecipada, diante da absoluta ausência de previsão legal, limitando-se o recebimento de tal instrumento processual somente em seu efeito devolutivo. Deste modo, alguns autores apontam que contra a decisão que homologa o laudo, em virtude de ter este caráter definitivo, caberá apelação, com fundamento no artigo 593, inciso II, do Código de Processo Penal ${ }^{58}$. Entretanto, no tocante ao recurso cabível da decisão que decreta a alienação antecipada, entende-se como inexistente qualquer previsão legal de recurso a ser manejado, razão pela qual Pacelli argumenta pela aplicabilidade do Recurso em Sentido Estrito ${ }^{59}$, não sem deixar de indicar- diante da negativa de admissibilidade do efeito suspensivo do recurso (art. 4 A§ 9, da Lei $12.683 / 12$ ) - que a impetração do mandado de segurança restaria como instrumento efetivo para a obtenção de liminar suspensiva da alienação ${ }^{60}$.

Realizado o leilão, a quantia apurada será depositada em conta judicial remunerada, adotando-se a disciplina delineada no $\$ 4^{\circ}$, do art. 4-A, da Lei 9.613/98 e, após o trânsito em julgado da sentença proferida na ação penal será, em caso de sentença condenatória, nos processos de competência da Justiça Federal e da Justiça do Distrito Federal, incorporado definitivamente ao patrimônio da União, e, nos processos de competência da Justiça Estadual, incorporado ao patrimônio do Estado respectivo. Em caso de extinção de punibilidade, os valores serão colocados à disposição do réu pela instituição financeira, acrescido da remuneração da conta judicial (art. 4-A, §§ $4^{\circ}$ e $10^{\circ}$ da Lei 9.613/98).

Imperioso ponderar, todavia, a existência de situações onde, dada a peculiaridade de suas características, o caráter infungível do bem, a alienação antecipada se revela inconveniente. Veja-se, por exemplo, a hipótese em que a indisponibilidade diga respeito a obras de arte, jóias de família, ou o imóvel de residência ${ }^{61}$. Em tais quadros fáticos, a

\footnotetext{
${ }^{58}$ BADARÓ, Gustavo Henrique; BOTTINI, Pierpaolo Cruz. Op. Cit..p. 333.

${ }^{59}$ OLIVEIRA, Eugênio Pacelli. Curso de Processo Penal. $16^{\mathrm{a}}$ ed. Atual. São Paulo: Editora Atlas, 2012.p.8.

${ }^{60}$ Ibidem. p. 8-9

${ }^{61}$ DE OLIVIERA, Marcelo Ribeiro. Op. Cit.,p. 668
} 
determinação de um administrador judicial se revelaria como solução mais adequada à preservação do valor da res sobre a qual recai a indisponibilidade.

Contudo, ao eleger quem ficará encarregado da administração do bem, não se poderá perder de vista a finalidade da medida motivadora da constrição, sob pena de frustrar as razões que the deram ensejo, como no cenário de definir o próprio acusado, ou investigado, pelos crimes de lavagem de dinheiro, como administrador da pessoa jurídica que the servia de instrumento à prática de ilícitos penais, "permitindo a ele não apenas a fruição do produto do crime, como a manutenção de eventual modus operandi de lavagem" ${ }^{62}$. Badaró e Bottini anotam pela aplicação do regime geral do Código de Processo Penal, onde a nomeação de administrador segue como medida excepcional. Para citados autores, nos casos onde há o desapossamento, o bem deve ser confiado a um depositário. Já nos casos em que não há o desapossamento sequestro de bens imóveis, especialização e registro da hipoteca legal e arresto prévio -, o bem deve permanecer com seu titular ${ }^{63}$.

Por certo, parece razoável que, nas situações onde a constrição se faz presente, por exemplo, sobre bens infungíveis, notadamente móveis, como obras de arte, e que não denotem uma propensão à desvalorização patrimonial com o decurso do tempo, mas tão somente demandem especial forma de guarda e manutenção para evitar sua depreciação, a medida mais indicada seria a nomeação de administrador judicial, não devendo se confundir, entretanto, com a pessoa do acusado/ investigado, afastando-se a previsão da alienação com base na parte final do $\$ 1^{\circ}$, do art. $4^{\circ}$, da Lei $9.613 / 98$ - “dificuldade para manutenção”. Nesse sentido verifica-se a jurisprudência do Superior Tribunal de Justiça:

[...] Ocorre que, no caso dos autos, não há dúvida de que o bem apreendido pertence ao recorrido, além do que interessa ao processo, porquanto há indícios suficientes de que o mesmo foi adquirido como produto do crime de lavagem de capitais, sendo que, nos termos do art. 119 do Código de Processo Penal, mesmo após o trânsito em julgado da sentença final, não poderá o veículo ser restituído ao seu proprietário, salvo no caso de ser absolvido na ação penal, é dizer, caso fique provado que o automóvel foi adquirido de forma lícita. Assim, não se tratando de lesado ou terceiro de boa-fé, mas sim de réu em ação penal, não se mostra razoável a devolução o produto do crime ao suposto criminoso, ainda que como fiel depositário, situação que, conforme bem ressaltado no voto divergente, "representaria uma ruptura do próprio sistema processual penal. (RECURSO ESPECIAL No 1.134.460 - SC - 2009/0143805-2) ${ }^{64}$

\footnotetext{
${ }^{62}$ DE OLIVEIRA, Marcelo Ribeiro. Op. cit. p. 667.

${ }^{63}$ BADARÓ, Gustavo Henrique; BOTTINI, Pierpaolo Cruz. Op. Cit. p. 346.

${ }^{64}$ BRASIL. Superior Tribunal de Justiça. Acórdão de decisão que autorizou a alienação antecipada de veículo automor apreendido em ação penal. Recurso Especial n. ${ }^{\circ} 1.134 .460 / S C$. Relator: Ministro Marco
} 
A indicação de administrador judicial para gerir os bens constritos traz, entretanto, outros inconvenientes, tais qual, a dificuldade em encontrar-se sujeito de confiança do Juízo e que aceite os encargos desta atuação. Além disto, a má administração dos bens poderá acarretar à perda ou perecimento dos objetos, ou, ainda, à depreciação de seu valor econômico, mais uma vez frustrando-se o propósito de manutenção do valor venal do patrimônio apreendido, ainda que assegurada a fiscalização do administrador judicial pelo Ministério Público, assim como sua responsabilização pela eventual má gestão do patrimônio a ele foi confiado ${ }^{65}$.

Notadamente, acerca dos inconvenientes da prática de indicação de depositário para gerir os bens e valores constritos, cite-se o episódio amplamente divulgado acerca do magistrado federal flagrado fazendo uso para fins pessoais de bens móveis apreendidos no decorrer da ação penal cuja condução estava sob sua responsabilidade. Neste mesmo quadro, posteriormente fora constatado o extravio de valores igualmente constritos a título de provimento cautelar. Embora tal fato de per si já cause espanto, em entrevista posterior referido magistrado declarou "que a utilização de bens apreendidos pela Justiça "seria uma prática normal, adotada por vários juízes" ${ }^{\circ 6}$.

Sobreleva ressaltar a repercussão negativa de tais manifestações, por esbarrar em questões sensíveis à noção de justiça. Tais fatos culminaram com a abertura de procedimento administrativo e ação penal em face do citado julgador, assim como em manifestação da Associação dos Magistrados Brasileiros no sentido de esclarecer que as condutas por ele apontadas como "naturais à prática forense" são, em verdade, vedadas e não usuais na magistratura ${ }^{67}$.

\footnotetext{
Aurélio Bellizze. 23 de outubro de 2012. Disponível em: < http: / /www.stj.jus.br/SCON/jurisprudencia/doc.jsp?livre=1134460\&\&b=ACOR\&p=false\&l=10\&i=4>. Acesso em: 20 jul. 2015.

${ }^{65}$ Nesse sentido aponta-se a ausência de previsão legal quanto ao regime jurídico de responsabilização do administrador judicial de que trata de lei de lavagem de dinheiro. Enquanto BADARÓ e BOTTINI expressam em responsabilidades inerentes ao depositário, José Paulo Baltazar JUNIOR e Sergio Fernando MORO, admitem que o administrador judicial encontra-se na condição de funcionário público equiparado, nos termos do artigo 327, do Código Penal, e nestes termos deveria ser responsabilizado pela má gestão do patrimônio que the foi confiado. Veja-se: JUNIOR, José Paulo Baltazar; MORO, Sergio Fernando. (Org.) Lavagem de Dinheiro - comentários à lei pelos juízes das varas especializadas em homenagem ao Ministro Gilson Dipp - Porto Alegre: Livraria do Advogado, 2007, p. 182; e BADARÓ, Gustavo Henrique; BOTTINI, Pierpaolo Cruz. Op. Cit. p. p. 346.

${ }_{66}$ Disponível em: http://www.conjur.com.br/2015-mar-12/mpf-prisao-preventiva-juiz-eike-batista. Acesso em 12 jun. 2015.

67 Disponível em: http://asmego.org.br/2015/02/25/amb-esclarece-em-nota-sobre-declaracao-de-juizque-utilizou-carro-de-eike-batista/. Acesso em 28 set. 2015.
} 
Digno de nota, a alienação antecipada tal qual positivada no art. 144-A do Código de Processo Penal não revela significativos pontos de divergência em relação ao instituto aplicável aos crimes de branqueamento de capitais, muito embora não seja difícil notar a especial atenção dispensada pelo legislador da Lei $12.683 / 12$, onde se preocupou em disciplinar a matéria de maneira minuciosa.

Ambos diplomas legais preveem o mesmo procedimento para requerimento, avaliação e leilão do patrimônio constrito, divergindo tão somente no percentual mínimo pelo qual o bem poderá ser leiloado. Enquanto o Código de Processo Penal fala em $80 \%$ do valor da avaliação, o legislador da Lei $12.683 / 12$ entendeu o quantum de $75 \%$ do valor da avaliação como o mais adequado aos propósitos do instituto ali consagrado. Superada eventual incongruência, concluise que não importará em problemas de ordem prática, pois cada diploma normativo tem seu âmbito de aplicação bem delineado.

Ponto passível a ensejar dúvida refere-se ao exato cabimento da alienação antecipada do Código de Processo Penal. Ao revés do observado na lei especial, o artigo 144-A da lei penal adjetiva define: “o juiz determinará a alienação antecipada para preservação do valor dos bens (...)”, abstraindo, todavia, qual a natureza da medida cautelar que originou a constrição do patrimônio submetido à alienação.

Ante o silêncio legislativo, a solução reside no artigo 144, do Código de Processo Penal, ao qual, por inequívocas razões de hermenêutica jurídica, reporta-se o artigo 144-A, do mesmo Códex. Todavia, mencionado dispositivo cita apenas as medidas assecuratórias do arresto de bens imóveis, arresto de bens móveis e da hipoteca legal, todas medidas cautelares reais a qual possuem um único ponto em comum: recaem sobre bens cuja licitude da origem não se vê colocada em dúvida durante a investigação preliminar ou a instrução processual.

Precisamente, Pacelli faz ressaltar que a finalidade do instituto da alienação antecipada do Código de Processo Penal dirige-se não a uma política de recuperação de ativos - amplamente comentada no cerne da criminalidade reditícia - senão à tutela dos interesses das vítimas de crimes patrimoniais em geral, com o fito de garanti-lhes o ressarcimento pelos danos daí decorrentes, sejam eles materiais ou morais, assim como atuar como subsídio das custas e despesas processuais. Por esta razão, sob esta lógica, somente nas hipóteses de comprovado risco de perecimento ou desvalorização do bem seria possível admitir a alienação antecipada de bens sequestrados ${ }^{68}$.

${ }^{68}$ OLIVEIRA, Eugenio Pacelli. Op. Cit. p. 319-320 
ISSN 1981-3694

(DOI): $10.5902 / 1981369419655$

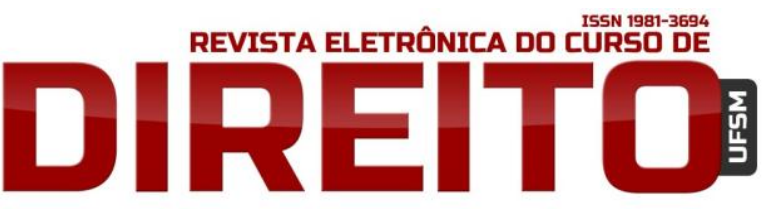

ALIENAÇÃO ANTECIPADA E DESTINAÇÃO PRÉVIA DE BENS CONSTRITOS: LIMITES ÉTICOS E JURÍDICOS NO ÂMBITO DA CRIMINALIDADE ECONÔMICA

Em efeito, sem deixar de lado as questões dogmáticas arguidas pelo douto processualista, de se concluir que a alienação antecipada, mesmo nos moldes tal qual disciplinado no CPP, exigirá do julgador uma análise casuística, atenta às peculiaridades da realidade onde se insere. Nesta medida, mesmo quando provenientes de busca e apreensão ou medida assecuratória de sequestro de bens, a venda "adiantada" do patrimônio constrito não poderá ser negada quando apresentar-se como única solução plausível à manutenção do valor venal da res sob custódia do Poder Público. Entender de modo diverso significaria desvirtuar a própria natureza do instituto, prejudicando o andamento processual e a possibilidade de um futuro provimento jurisdicional útil.

\section{CONCLUSÃO}

A mudança de paradigma dos delitos perpetrados na sociedade de risco moderna importou em demandas por novos instrumentos judiciais aptos a fornecer a devida e eficiente prestação jurisdicional, alternando-se de um enfoque sobre medidas cautelares pessoais para medidas assecuratórias. Seja nos dispositivos originários do Código de Processo Penal Pátrio, seja na legislação especial, premente reconhecer a nova responsabilidade do Poder Público em dar respostas a crescente criminalidade econômica e seus produtos ilícitos derivados. Tornou-se necessário apresentar um plano de ação, o qual se concentrou na fase de perquirição preliminar, para resolver justamente situações em que bens perdiam seu valor e se inutilizavam em razão da morosidade judicial, comprometendo tanto o interesse público, como as garantias individuais do jurisdicionado.

Destarte, novos mecanismos foram criados e normatizados, merecendo especial destaque o instituto da alienação antecipada de bens, cujo escopo originário era tutelar tão somente os danos causados as vítimas de crimes patrimoniais, em princípio. Todavia, face a nova política criminal e realidade forense de inúmeros objetos depositados em juízo sem qualquer destinação, nominada ferramenta assumiu o papel combativo a nova criminalidade, ao mesmo passo em que buscaria melhor aproveitar esses bens.

Para tal, prolatou-se variadas regras, contidas na Lei de Lavagem de Capitais (consoante alterações trazidas pela Lei 12.683/12), Lei de Combate ao Tráfico de Substâncias Entorpecentes, Portaria n. ${ }^{\circ} 3.010 / 2011$ da Receita Federal, entre outras já mencionadas. Tais 
ISSN 1981-3694

(DOI): $10.5902 / 1981369419655$

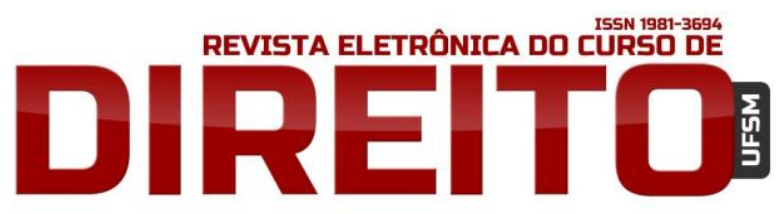

ALIENAÇÃO ANTECIPADA E DESTINAÇÃO PRÉVIA DE BENS CONSTRITOS: LIMITES ÉTICOS E JURÍDICOS NO ÂMBITO DA CRIMINALIDADE ECONÔMICA

textos legais abordam justamente a possibilidade de alienação antecipada e qual procedimento a ser adotado, embora ainda fazendo uso, em certas ocasiões, de regras do processo civil, subsidiariamente.

Nessa toada, insta salientar a imperiosa incidência de todas as garantias individuais atinentes ao processo penal quando da aplicação da venda antecipada de bens, pois não se pode perder de vista que, enquanto perdurar o procedimento da medida assecuratória, o investigado/réu estará sob o manto do princípio da presunção de inocência. De tal modo, aplicar-se-á a alienação antecipada de bens constritos por medidas cautelares reais quando for único deslinde possível para garantir a manutenção do bem, tal qual atender precipuamente o interesse público e a prevalência dos direitos e garantias do jurisdicionado.

Assim sendo, não se pode negar a importância de tal instituto como meio de atender os princípios constitucionais, em especial o tocante ao princípio da eficiência, concretizado no art. 37 da Constituição Federal. Porém, torná-lo meio irrestrito de esvaziamento de pátios de delegacia, depósitos judiciais e de resposta do Estado aos delitos de colarinho branco e afins, fere os limites éticos e legais estabelecidos no escopo do Estado Democrático de Direito.

Portanto, não se pode olvidar da prevalência das garantias individuais do sujeito submetido a mais uma ferramenta estatal de persecução. Ora, negar que nominados procedimentos sejam completamente isentos de influência sobre atual ou futuro processo criminal em curso é ilógico, contudo deve sempre imperar a ponderação e a presunção de inocência em tais situações, ao passo em que ainda vige no ordenamento pátrio - mesmo que de forma cada vez mais relativizada, erroneamente - a máxima onde somente se considera culpado após o trânsito em julgado da sentença penal condenatório. A alienação antecipada de bens constritos não pode ser subjugada ao anseio social e Estatal de ressarcir os cofres públicos tão somente porque existe investigação preliminar e/ou meros indícios de cometimento do delito, pois se trata de medida processual, prima facie, e não cominação sancionatória de plano. 


\section{REFERÊNCIAS}

BRASIL. Lei $n^{\circ} 6.938$ de 31 de agosto de 1981. Dispõe sobre a Política Nacional do Meio Ambiente, seus fins e mecanismos de formulação e aplicação, e dá outras providências. In: Diário Oficial da República Federativa do Brasil, Brasília, DF, 02 set. 1981. Disponível em: <http://www.planalto.gov.br/ccivil_03/Leis/L6938.htm>. Acesso em: 09 jun. 2007.

ACCIOLY, Maria Francisca dos Santos. As medidas cautelares patrimoniais na lei de lavagem de dinheiro. Rio de Janeiro: Lumen Juris, 2014.

AGUADO CORRÊA, Tereza. Decomiso de los productos de La delincuencia organizada "garantizar que El delito no resulte provechoso". In: Revista Eletrônica de Ciência Penal y Criminologia. REPC 15-05 (2013). Disponível em: http://criminet.ugr.es/recpc.

ALEIXO, Márcia Lúcia Clemente Neto. Alienação antecipada de bens e valores no crime de "lavagem de dinheiro" e o devido processo penal. In Anais do XVII Congresso Nacional do CONPEDI, Brasília. Novembro de 2008.

ALVES, Rogério Pacheco. O Poder Geral de Cautela no Processo Penal. In: Revista EMERJ, v. 6, n. 22, 2003.

BADARÓ, Gustavo Henrique; BOTTINI, Pierpaolo Cruz. Lavagem de Dinheiro: aspectos penais e processuais penais: comentários à Lei 9.613/98, com as alterações da Lei 12.683/12. São Paulo: Revista dos Tribunais, 2012.

BARROS, Marco Antônio de. Lavagem de capitais e obrigações civis correlatas: com comentários, artigo por artigo, à lei 9.613/1998. $4^{\text {a }}$ ed. rev., atual., e ampl. São Paulo: Revista dos Tribunais, 2013.

BOTTINI, Pierpaolo Curz. O Enriquecimento ilícito e a presunção de inocência. In: Revista Consultor Jurídico. Disponível em http://www.conjur.com.br/2012-mai-08/direito-defesaenriquecimento-ilicito-presuncao-inocencia.

BRASIL. Lei no 9.613 de 03 de março de 1998. Dispõe sobre os crimes de "lavagem" ou ocultação de bens, direitos e valores; a prevenção da utilização do sistema financeiro para os ilícitos previstos nesta Lei; cria o Conselho de Controle de Atividades Financeiras - COAF, e dá outras providências.. In: Diário Oficial da República Federativa do Brasil, Brasília, DF, 04 mar. 1998. Disponível em: <http://www.planalto.gov.br/ccivil_03/Leis/L9613.htm>.

Superior Tribunal de Justiça. Acórdão de decisão que autorizou a alienação antecipada de veículo automor apreendido em ação penal. Recurso Especial n. ${ }^{\circ} 1.134 .460 /$ SC. Relator: Ministro Marco Aurélio Bellizze. 23 de outubro de 2012. Disponível em: < http: / / www.stj.jus.br/SCON/jurisprudencia/doc.jsp?tivre=1134460\&\&b=ACOR\&p=false\&l=10\& $\mathrm{i}=$ 4>. Acesso em: 20 jul. 2015. 
CAEIRO, Pedro. Sentido e função do instituto da perda de vantagens relacionadas com o crime no confronto com outros meios de prevenção da criminalidade reditícia. In: Revista Brasileira de Ciências Criminais. Ano 21. Vol. 100. Jan-fev./2013.

CALLEGARI, André Luís. Direito Penal Econômico e Lavagem de Dinheiro - aspectos criminológicos. Porto Alegre: Livraria do Advogado. 2003.

CARVALHOSA, Modesto. Considerações sobre a Lei anticorrupção das pessoas jurídicas: Lei n. 12.846 de 2013. São Paulo. Revista dos Tribunais. 2015.

CORREGEDORIA NACIONAL DE JUSTIÇA. Manual de bens apreendidos - CNJ. Disponível em http://www.cnj.jus.br/images/corregedoria/MANUAL_DE_GESTO_DE_BENS_APREENDIDOS_cd.pd $\underline{f}$

CORRÊA, João Conde. Da Proibição do Confisco à Perda Alargada. Lisboa: INCM - Imprensa Nacional Casa da Moeda: Procuradoria Geral da República. 2012.

CORRÊA JUNIOR, Alceu. Confisco Penal. Alternativas á prisão e aplicação aos delitos econômicos. São Paulo. IBCCRIM, 2006.

DE CARLI, Carla Veríssimo. Lavagem de Dinheiro: ideologia da criminalização e Análise do discurso. 2 ed. Porto Alegre: Verbo Jurídico, 2012.

DE OLIVIERA, Marcelo Ribeiro. Provimentos Cautelares Patrimoniais em Lavagem de ativos. In Lavagem de dinheiro - prevenção e controle penal, Carla Veríssimo de. (Coord.). $2^{\mathrm{a}}$ ed. Porto Alegre: Editora Verbo Jurídico, 2013.

FIGUEIREDO DIAS, J. de. O direito penal entre a 'sociedade industrial' e a 'sociedade do risco'. In: Revista Brasileira de Ciencias Criminais, São Paulo. n. 33, 2001.

Direito penal, parte geral, tomo I: questões fundamentais: a doutrina geral do crime. $1^{\text {a }}$ edição. São Paulo: Revista dos Tribunais. 2007.

FREITAS, Vladimir Passos de. O desafio dos bens apreendidos nas ações penais. Revista Consultor Jurídico. Disponível em: http://www.conjur.com.br/2011-out-23/segunda-leituradesafio-bens-apreendidos-acoes-penais.

HASSEMER, Winfried. Processo Penal e Direitos Fundamentais. In. Jornadas de Direito Processual Penal e Direitos Fundamentais (Coord. Maria Fernanda Palma). Coimbra: Almedina, 2004.

LEITE, Larissa. Medidas patrimoniais de urgência no processo penal - implicações teóricas e práticas. Rio de Janeiro: Renovar, 2011.

LOPES JR., Aury. Direito processual Penal. 9ª ed. rev. E atual. São Paulo: Saraiva, 2012.

LOPES JR., Aury; GLOECKNER, Ricardo Jacobsen. Investigação Preliminar no Processo Penal. 5. Ed. rev., atual. e ampl. São Paulo: Saraiva, 2013. 
MARQUES, José Frederico. Tratado de Direito Processual Penal. São Paulo: Saraiva, 1980.

PACELLI, Eugenio. Curso de Processo Penal. 17 ed. rev., ampl e atual. São Paulo: Atlas, 2013.

PALUDO, Januário. Recuperação de Bens. In Lavagem de dinheiro - prevenção e controle penal, Carla Veríssimo de. (Coord.). 2 $2^{\mathrm{a}}$ ed. Porto Alegre: Verbo Jurídico, 2013.

PITOMBO, Antônio Sérgio A. de Moraes. Lavagem de Dinheiro: A tipicidade do crime antecedente. São Paulo: RT, 2013.

POLASTRI, Marcellus. A tutela cautelar no processo penal. $3^{\text {a }}$ ed. São Paulo: Atlas, 2014.

PONS, Noël. La corruption des elites: expertise, lobbying, conflits d'intérêts. Paris: Odile Jacob, 2012.

RECEITA FEDERAL DO BRASIL. Portaria n. ${ }^{\circ} 3.010$ de 29 de junho de 2011. Estabelece critérios e condições para destinação de mercadorias abandonadas, entregues à Fazenda Nacional ou objeto de pena de perdimento; altera a Portaria RFB $n^{\circ} 2.206$, de 11 de novembro de 2010, que regulamenta o leilão, na forma eletrônica, para venda para pessoas jurídicas de mercadorias apreendidas ou abandonadas; e dá outras providências. In: Diário Oficial da República Federativa do Brasil, Brasília, DF, 06 jul. 2011. Disponível em: < http://normas.receita.fazenda.gov.br/sijut2consulta/link.action?idAto=30643\&visao=anotado>.

SCHÜNEMANN, Bernd. Consideraciones Críticas sobre la situación espiritual de la ciência jurídico penal alemana. In: cuadernos de Doctrina y Jurisprudencia Penal, Buenos Aires, n. 2, p. 17-49, abr. 1996. Disponível em: http://derechopublicomd.blogspot.com.br/2012/05/consideracionescriticas-sobre-la.html.

SILVA SANCHEZ, Jesús-María. A expansão do direito penal: aspectos da política criminal nas sociedades pós-industriais (Trad. Luiz Otavio de Oliveira Rocha). In: Séries As ciências criminais no século XXI, v. 11). São Paulo: Revista dos Tribunais. 2002.

SIMÕES, Euclides Damásio; TRINDADE, José Luis F.. Recuperação de Ativos: Da perda ampliada à actio in rem (virtudes e defeitos de remédios para patologias graves). In: Revista Julgar online 2009. Disponível em: < http://julgar.pt/recuperacoes-de-activos-da-perda-ampliada-a-actio-in$\mathrm{rem} />$.

TUMA JÚNIOR, Romeu. Combate à lavagem de dinheiro e corrupção - Os frutos da parceria entre o Ministério da Justiça, a Advocacia-Geral da União e outros órgãos do Estado brasileiro. In: Debates em Direito Público, Belo Horizonte, Ano 8, n. 8, Out. 2009. Disponível em: <http://bid.editoraforum.com.br/bid/PDlexibepdf. aspx?tipoConteudo=Normal\&vw=S\&pdiCntd=7 2408\&idPublicacao=30>.

Recebido em: 28/09/2015 / Revisões requeridas em: 09/11/2015 / Aprovado em: 11/11/2015 